\title{
Haptic Thinking and Experience through Collective Artistic Research
}

\author{
Pensamento e experiência táteis através da \\ investigação artística coletiva
}

\section{Pensamiento y experiencia táctil a través de la investigación artística colectiva}

\begin{abstract}
Dasha Lavrennikova *
Institute of the Arts Barcelona, Espanha

https://doi.org/10.22409/poiesis.v20i34.38294

RESUMO: This article offers a theoretical reflection and practical proposals from the HeterotRópico artistic laboratory, a nomadic laboratory - where we are investigating dance, performance, physical theater, in conjunction with other diverse social technologies. They bring tools to activate collective practices developed within open creative processes. We will focus on the seminar lab I have proposed at the Masters in Arts Practice and Visual Culture 2018-2019 in Madrid, bringing together an intercultural group of artists and thinkers of around practices of transdisciplinary arts. Artistic laboratories, in the diverse formats that they are defined today, aim to activate a field of subjectivities and corporeality, explored and coproduced in their uniqueness during the artistic process.
\end{abstract}

KEYWORDS: artistic laboratory; corporeality; subjectivity; presence

\footnotetext{
* Dasha Lavrennikova é coreógrafa, performer, curadora, professora e pesquisadora do movimento do Institute of the Arts Barcelona, Sitges, Espanha. E-mail: Dasha.Lavrennikov@gmail.com. Orcid: http://orcid.org/0000-0001-5131-5318
} 
RESUMO: Este artigo oferece uma reflexão teórica e propostas práticas do laboratório artístico HeterotRópico, um laboratório nómade - onde estamos investigando dança, performance, teatro físico, em conjunto com outras tecnologias sociais diversas. Eles trazem ferramentas para ativar práticas coletivas desenvolvidas dentro de processos criativos abertos. Vamos nos concentrar no laboratórioseminário que tenho proposto no Masters em Praticas Artísticas e Cultura Visual 2018-2019, em Madrid, reunindo um grupo intercultural de artistas e pensadores de práticas em artes transdisciplinares. Os laboratórios artísticos, das formas diversas que estão sendo definidos hoje, apontam para ativar um campo de subjetividades e corporalidade, exploradas e co-produzidos, em sua singularidade, durante o processo artístico.

PALAVRAS-CHAVE: laboratório artístico; corporeidade; subjetividade; presença

RESUMEN: Este artículo ofrece una reflexión teórica y propuestas prácticas del laboratorio artístico HeterotRópico, un laboratorio nómada, donde investigamos danza, actuación, teatro físico, junto con otras diversas tecnologías sociales. Traen herramientas para activar prácticas colectivas desarrolladas dentro de procesos creativos abiertos. Nos centraremos en el laboratorio-seminário que he propuesto en el Máster en Practica Escenica y Cultura Visual 2018-2019 en Madrid, que reúne a un grupo intercultural de artistas y pensadores de prácticas en artes transdisciplinarias. Los laboratorios artísticos, de las diversas formas que se están definiendo hoy, tienen como objetivo activar un campo de subjetividades y corporeidad, explorado y coproducido en su singularidad durante el proceso artístico.

PALABRAS CLAVE: laboratorio artístico; corporeidad; subjetividad; presencia

Citação recomendada:

LAVRENNIKOVA, Dasha. Haptic Thinking and Experience through Collective Artistic Research. Poiésis, Niterói, v. 20, n. 34, p. 159-182, jul./dez. 2019.

[https://doi.org/10.22409/poiesis. v20i34.38294]

Dasha Lavrennikova, Haptic Thinking and Experience through Collective Artistic Research. 


\section{Haptic Thinking and Experience through Collective Artistic Research}

The notion of existence involves the notion of an environment of existences and of types of existences. Any one instance of existence involves other existences, connected with it and yet beyond it. This notion of the environment introduces the notion ... of multiplicity.

-- Alfred North Whitehead, Modes of Thought.

Within the contemporary arts, on the thresholds and frontiers of the performing, performance, visual, conceptual and media arts, the artistic laboratory is as an evolving concept, format, and process that is in collective multi-directional and multi-generational construction. It is a processual zone dedicated to artistic, micro-political and social experimentation; a trans-disciplinary field of knowledge based artistic practice that we can also refer to as "research- creation" $^{11}$. (MASSUMI; MANNING, 2014) The range of organizational and improvisational structures that sustain and characterize each arts lab that is elaborated vary depending on the epistemological and artistic fields that its proposers depart from and evoke, throughout the process (be it dance, 


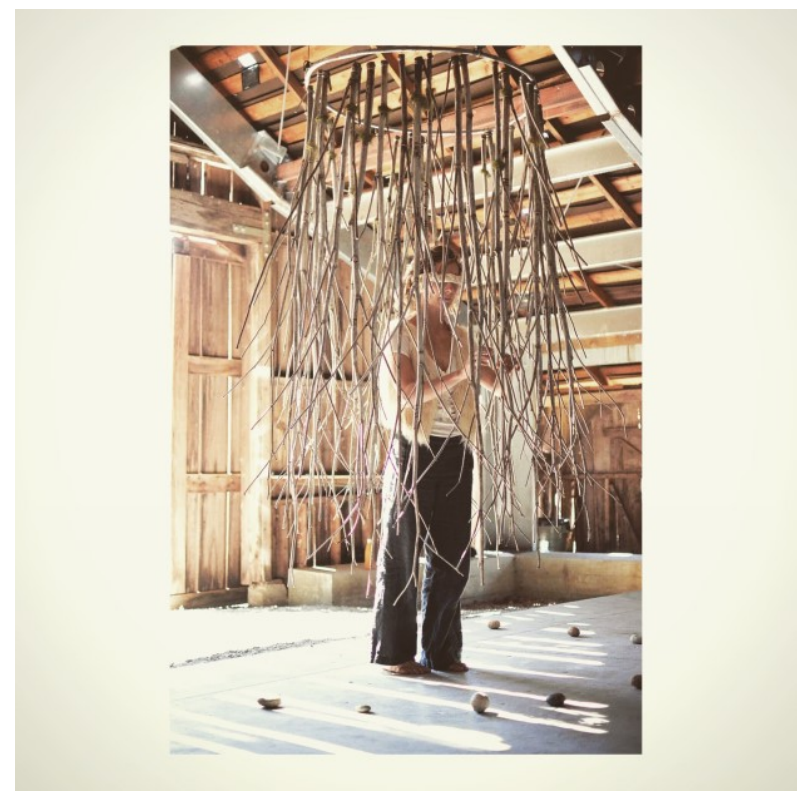

Fig. 1 - Dasha Lavrennikov, Tracing Bones Performance, Djerassi Resident Artist Program with Anya Yermakova and Sebastian Perez. California, 2018.

(Photo: Resident Photographer) 
theatre, media arts, visual arts, performance art, live art, anti-art etc.). This refers to the kinds of thought apparatuses that are employed (empirical/theoretical/ ontological), and the perceptual environments that are cultivated throughout the laboratory: that is, the methods, modes, structures, tools and technologies for perceiving, tuning, embodying, co-creating, improvising, composing, inventing, and communicating that are used, elaborated and shared in the open ended process. The theoretical reflections discussed in this article are directly and indirectly influenced by my Ph.D. research-creation project titled, "Sensing Bodies. Fields of Presences in Motion: Laboratories of Dance and Collective Practices" that enters into dialogue with a concrete dance arts laboratory that I developed, carried out and documented in Rio de Janeiro and Minas Gerais, Brazil and now continue to work with in my artistic and pedagogical practices in Europe.

In the suspended time-space of collective research-creation, a group engages in a philosophy in action, shifting beyond dualistic and binary paradigms both in relation to the body as well as in relation to thought, language, knowledge and culture. The par- ticipants of an arts lab accompany one another's co-production of corporeality and subjectivity, through the practices of sharing, performing, witnessing and offering feedback in the creative process. This stimulates a collective orientation, disorientation and reorientation of the micropolitical, understood in the following terms:

\section{Micropolítica é o nome que Guattari deu, nos anos 80, aqueles âmbitos que, por serem considerados relativos à "vida privada" no modo de subjetivação dominante, ficaram excluídos da ação reflexiva e militante nas políticas da esquerda tradicional: a sexualidade, a família, os afetos, o cuidado, o cor- po, 0 íntimo. Tudo isso que depois Foucault tentará apontar com os termos "microfísica do poder" e mais tarde biopoder. (ROLNIK, 2014, p. 18-19)}

The arts lab is a space for experimenting with one's daily tendencies and patterns, as well as extra-daily counter fluxes, and subterranean becoming. How can life be lived and perceived otherwise, in relation to one's vibrations, pulsations, obsessions and vital forces: the body, the intimate, affectivity, relationality. These proposals are developed by way of group dynamics, games, tasks, scores and exercises that function as strategies to reach into and access layers of 
one's vitality and unconscious in motion, bringing them to the surface and manifesting them through poetic acts, writings, speech etc. (ROLNIK, 2014, p.18-19) These are elements of our private life that are not only almost never shared publicly, but are not even admitted or recognized in oneself, and yet they are subservient to the pulls of the neoliberal economy, and simultaneously contain a potentiality to subvert this subservience. Overconsumption, anxiety and various forms of oppression and violence drink from the same well of pulsating unconscious forces, as do our creative and transgressive potentials. Our skin, bones, muscles and breath patterns in motion, stillness and contact (with others and the world) reveal more than we can understand or interpret through conventional language, yet just enough to sense and intuit through haptic and aesthetic experiences. In the arts lab environment, we piece together a complex puzzle made up of the sensing self in relation to the sensitive environment; this is an endless yet fructiferous and fascinating task that reveals both familiarity and habituations in the encounter between self and world, as well as the possible detours and lines of flight. What moves you to move, write, improvise? What moves you to notice, to ignore, to care, to relate, to think, to understand, to transgress, to rebel, to repeat, to reproduce, to follow, to consent, to forget, to remember, to control, to surrender, and to oppress (self, others, and things)? What is an essential question for you? These are themes and questions that are channeled through different modalities of thought and creation.

In the arts lab space, through collective exercises and games that use: diverse parameters of improvisation, scores and tasks, enabling constraints, techniques of automatism, experimental multi-sensory walking (inspired by the Surrealist and Situationist movement), and techniques of defamiliarization, we can trigger, reveal and play with our ordinary and extraordinary habits, survival tactics, histories and lingering unknowns. With this material (dissolving binary logics of good and bad, right and wrong, object and subject, freedom and limitation) we construct, deconstruct and question reality through poetic and micropolitical proposals, interventions, and events. What appears paradoxical, in fact, reveals the complexity, interconnectivity and complementary opposites that characterize our relations, systems, and organ- 
isms. The utopian, dystopian and heterotopic qualities of our subconscious are intertwined in an ecology of experience, just as the ambiguity and shape shifting that permeates and colors our dreams, revealing other modalities of processing space-time. We challenge ourselves to unlearn and expand the way we relate to the world ingrained in everyday interactions (with self, things and others) and habituations, by playing with, disorienting and complicating familiar encounters. This is accompanied by returning to the senses (vision, hearing, touch, kinesthesis etc.), following features and actions in both our inner and outer environments: that is, a sense-action. To reach a state of unlearning and disorientation, we must first orient ourselves as constant containers and generators of imagery, thoughts and feelings. (MASSUMI; MANNING, 2014)

In the field of dance and performance, we do this through tuning practices, an example are the tuning scores developed by Lisa Nelson. These tuning practices are considered pre-techniques, maps to follow, with feedback systems to help observe one's patterns, process, strategies, and appetite for becoming physicalized. That is, the tools to observe and taste one's creative body before entering into preconceived forms and figures. With the tuning scores, Nelson as well as any individual can inquire into 1 . How we look at things 2. How we sense and make sense of movement. 3. How we expose opinions about space, time, action and desire 4. How we provide a framework for communication and feedback. 5. How we play with desire to compose experience and make our imaginations visible in the act (Little; Nelson, 2006). These elements are all part of an ecology of perception, the senses considered as a perceptual system. Moreover, the movement of the body and sensory organs is both exploratory and performatory. We are able to revise and play with our basic orienting, vestibular systems (auditory, haptic, taste, smell, visual). We have the capacity to loosen the bonds of our perceptual conditioning by way of play, visualization and improvisation, revisiting childlike and pre-naming states, animal and pre-vertebrae states, states attracted by things and forces. (LITTLE; NELSON, 2006) Thus, we develop a more flexible, heterogeneous, direct and dialogical construction of and with reality. What Lisa Nelson points out is that the exploratory behavior of our senses plays a central role in shaping and 
sculpting our opinions and aesthetic appetite, that is, how we move and what we see. Nina Little refers to this as a politics of attention, referring to touch as a sensory foundation of giving as well as the possibility of shifting self-sense and time sense (slow experiential generous time) through embodied practices. Little underlines the ethos of giving weight and attention, exposing social values and forms of relationality and reciprocity by way of structured improvisation practice. The multiple forms of "attentionality": giving attention, living attention, healing attention, oscillating attention, peripheral attention, spatial temporal attention etc. (LITTLE; NELSON, 2006)

We inhabit the arts lab space and the arts lab space inhabits us, the body and the arts lab are physical and living structures. Our own flesh and the flesh of the world are the core material and source of the arts laboratories that we discuss (Ponty, 2002]. Furthermore, we are engaging a body which 'daily rehearses and performs' civil obedience, resistance, citizenship, gender, ethnicity - the performance and aesthetic of everyday life in the public sphere - according to the performance studies scholar Diana Taylor (2003). The performance of eve- ryday life is in dialogue with 'rehearsing and performing' on the fringes and hybrid boundaries between what in performance and theater anthropology and studies is referred to as the daily and extra-daily (ordinary and extraordinary). The artist, performer and philosopher Vera Mantero describes the role of the laboratory as the space for this experimentation, subversion and interaction between the daily and extra daily. It is a space for perceiving, practicing and digesting how life, or some parts of life, could be, otherwise, acknowledging the challenges that this may present us in the process: "Knowing that I do not know what life is like otherwise, it is necessary to try out and see how it could actually be otherwise, in practice, through the experience and in relationality, minimally, as it could be perceived in a laboratory and not in ordinary life". (MANTERO 2014, p. 2) Thus, in the arts lab there is an urgency in the task of collectively researching, rehearsing, experimenting, creating and performing 'operations and acts of re-existence', 'gestures of resistance' and extra-dailyness.

A focal point of the arts labs I have been participating in and facilitating has been to elaborate modes of generosity and care in 
response to the structural and physical violence that has traumatized and continues to traumatize the body with its individual and collective imaginary. In spite of, and in response to the normalizing and oppressive vision and training of the body both in daily life as well as in certain performing arts practices, the choreographer Boriz Charmatz offers a reflection on the attraction towards the genesis of unknown heterogenous bodies and the extra daily, through aesthetic experiences that move between action, kinesthetic and visual imagery and languages, exploring the functional, metaphorical, symbolic and poetic:

\section{It is far more gratifying to think that work in dance, far from being a quest for an ideal body, invents heterogeneous bodies, bodies that are more desir- ing than in everyday life, bodies that are more de- cisive, more clumsy, more abandoned, more virile, more feminine, more vegetable, more mineral, more 'machine life', more childlike, more aged, etc.. or all this at the same time. It is not a matter of establishing a panoply of different bodies, but of opening up different modes of occupying the body. (PEETERS, 2004, p. 68-69)}

This is interrelated with the intention to access ones embodied knowledge through "ex- periencing the imagination", a phrase the Brazilian anthropologist and critical thinker Viveiros de Castro uses, which he clearly differentiates from "imagining the experience". (VIVEIROS DE CASTRO, 2002, p. 50) A point of inspiration for both Viveiros de Castro, as well as for this article, are the French anthropologist's Levi Strauss's reflections on the potential of a wild, unsubordinated, and sensorial side of our minds and bodies, in his work "The Savage Mind". (LEVI-STRAUSS, 1966) He reminds us that the science of concrete mythical thought is prior to scientific inquiry, and that both thought forms are valid and should be given the space to develop themselves. Expressed simply, he differentiates them in that mythical thought is based on observation of the sensible world in sensible terms, while science forges new systems of knowledge. Art and philosophy for Levi Strauss lie between magic and science, balancing structure and event, engaging between the mythical and scientific thought, between the practical and theoretical, the material and immaterial, the metaphorical, symbolic and poetic, the visible and invisible. (LEVI-STRAUSS, 1966, p. 26-30) The arts lab is nurtured, in part, by our wild unsubordinated and multi-sensory states of mind-body. 


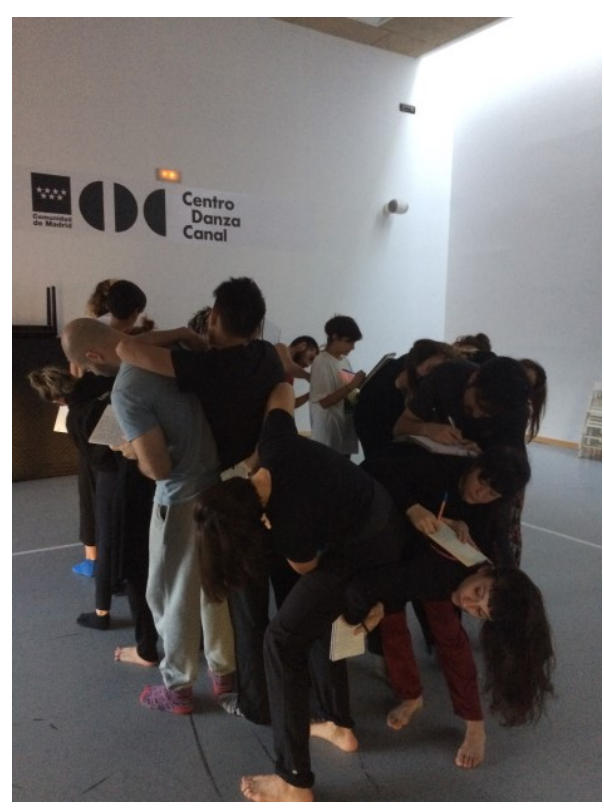

Fig. 2 - Dasha Lavrennikov, HeteroTRopical Arts Lab Seminar, with students from the Arts Practice and Visual Culture Masters, Madrid, 2018.

(Photo: Dasha Lavrennikov)

Dasha Lavrennikova, Haptic Thinking and Experience through Collective Artistic Research. 


\section{HeterotRopical Arts Lab}

Focusing in, on what I refer to as, the HeterotRopical Arts Lab, this is a nomadic laboratory, experimenting the zones of a heterotopia, where we have been investigating dance, performance, physical theatre, alongside other diverse social technologies (such as Dragon Dreaming and Deep Ecology), as tools for activating collective practices structured by open ended creative processes. We will zoom into one example of this approach proposed in a laboratoryseminar that I facilitated in the Masters in Arts Practice and Visual Culture 2018-2019, in Madrid. This is a collaboration between university, museum, gallery and theatre spaces bringing together artists and scholars from transdisciplinary arts practices, from diverse countries of Latin America and EuropeMy artistic, pedagogical and research trajectory, as well as the foundational principles that guide the innovative field of research - creation, sustaining and inspiring the practices I integrated in the context of the arts lab-seminar in Madrid, come from the fields, circuits, and undergrounds of contemporary art, philosophy, art theory, dance, theatre, and performance studies, critical theory, cultural and communication studies, anthropology, indigenous and black studies, critical psychoanalysis and psychogeography, and cognitive studies.

In specific, my pedagogical and artistic approach is greatly influenced by the following artists and scholars, amongst others, all of whom worked through collaboration and contagion: Brian Massmumi and Erin Manning (Sense Lab), Tina Little, Lisa Nelson and Steve Paxton (precursors of CI and postmodern dance), Hélio Oiticica, Lygia Clark, Mario Pedrosa (precursors of Neo Concretist Movement), Vera Manteiro and André Lepecki (investigation and creation partnership), Suely Rolnik and Peter Pál Pelbart (Nucleus of Subjectivity Studies, cartographic practices and indigenous studies), Fred Moten and Stefano Harney (undercommons: Fugitive planning and black studies), and last but not least, Deleuze and Guattari (production of subjectivity, processual creativity and schizoanalytic cartography). What these artists and philosophers have in common, regardless of how they name and conceptualize ideas and things, is a commitment to 'thought in the act'; bodily thinking; amplitude and ecology of perception; sensing the sensitive environment; 'ecology of experience', openended creative process, collaborative multi- 
voiced practices, epistemological justice (neurodiversity), and micropolitical operations reaching beyond the pushes and pulls of the neoliberal economy.

It is important to reiterate that the heterotRopical arts lab I propose, as well as the Sense lab (proposed by Massumi and Manning), the lab of observation and vibrations (proposed by Vera Manteiro), and the paralaboratory (conceptualized by Mario Pedroso), are all part of a larger phenomenon (varying in scales of public participation). That is, an urgent global call for the growing engagement of experimental artistic languages - visual and performative - in social, collaborative and collective practices in the contemporary art world. It is a time and space dedicated to tuning, questioning, studying, testing, training, rehearsing and investigating how the collective and singular production of presence and meaning (GUMBRECHT, 2003) locally, can potentially be expanded and amplified towards a shared field of action, resistance, reexistence and care glocally. This is part of an emerging ethical aesthetic paradigm, towards a practice of ecosophy, which is explored and defined by Felix Guattari in his book The Three Ecologies: 1. Human sub- jectivity (mental ecology) 2. Social relations (social ecology) 3. The environment (environmental ecology), not distinct, but formed relationally and transversally. Guattari calls for dissident vectors, through the articulation of aesthetic and social practices, that run counter the normal order of things, meeting and surpassing the intensive and extensive reaches of neoliberalism. (GUATTARI, 2000) That is, by way of the vital forces (mental, relational, environmental) in their process of emergence, mutation, becoming and reinvention: aka, creative lines of flight. In the context of openended arts practices of the arts lab, with collective aims for creative expression, suspending authorial will, these invisible yet palpable forces fluctuate, vibrate, bifurcate, and are filtered through and by way of the 'knowing body', collective imaginary, and the unconscious. This commitment to creative lines of flight likewise invoques and finds inspiration in the anti-psychiatric movement, led by Deleuze and Guattari (in France), and recontextualized by Rolnik and Pelbart (in Brazil), as well as Massumi and Manning (in Canada and internationally), in different therapy art situations. "Que Suely Rolnik leva de sua passagem por La Borde [com Guattari] e seu retorno para o Brasil é 
a afirmação da cena de criação artística como um lugar de trabalho micropolítico e clínico. (ROLNIK, 2014, p. 18) There is a shared intention to move beyond binary logics, dissolving classical oppositions between theory and practice, the poetic and political, representation and action, art and therapy, through a commitment to decolonize the unconscious through a forest thinking. According to Rolnik, any process of political transformation that does not take into account the decolonization of the unconscious is bound to repeat its forms of oppression. What are the strategies for supporting and elaborating molecular revolution? One possibility is insisting on developing experimental approaches within creative processes that permit us to rename, sense (feel) and perceive the world. The micro political transformation of the unconscious directly resonates on how one perceives and interprets the world. Within the artistic labs, and throughout many artistic processes, the unconscious is a primal source and force of creation and expression connected with a "vital pulse" ("potencia guadendi" Espinosa). Rolnik insists on a politics of dissident subjectivities, allowing for the reappropriation of one's vital potential of creation and development of what she refers to as "saber-do-corpo", that is, the knowledge of our condition as living beings. In contrast and opposition to recipes of instant happiness, she invites us to "sustain the discomfort (mal estar)", a micro political condition of resistance. The discomfort that these kinds of ruptures produce can be sustained and transformed. "uma política de subsolo, subterranean, uma política sob a pele, sob a terra, uma esquerda clorofílica ou telepática, ali onde a planta e o pensamento se conectam através da imagem ou da poção [...] (ROLNIK, 2014, p. 20-21). Here, a reference is being made to a kind of forest thinking, a commitment to perceptual variation and neurodiversity, that illustrates the creative potential and diversity of perspectives across different modalities of thought and modes of existence (states of mind that are neurologically, energetically, physiologically diverse).

These tendencies are in resonance with the broadening notions of interdependence, the politics of perception, as well as cognitive and epistemological justice, which all work towards cultivating the creative agency of a new protagonist-participant as well as the creative generosity of the proposer, shifting away from the passive spectator, and all 
enlightened artist. As a result, this has been provoking epistemic, ethical and aesthetic changes in the formats of artistic creation and validation, no longer based on consumable, spectacular products but on immersive, multi-sensory, durational, critical collective processes that have the capacity to shift the value of things. According to Helio Oiticica, an important artistic experimenter and reference for the research-creation processes both in Brazil and internationally, the function of art is not to yield to the production demands of the work, but to change the value of things. Thus, Oiticica challenges many of the foundations of art with new categories, like the visual experience in what he referred to as the penetrables, the object or the public intervention in parangolés, giving rise to an artistic practice based on the alliance between awareness and sensation, relationships and experience, language and form(less). (OITICICA, 1972)

The arts lab proposals are likewise in resonance with and inspired by Hélio Oiticica's trajectory and philosophy, in response to a need that comes from the contemporary society to displace the centrality and elitism of the artistic field, providing strategies for activating alternative modes of being together creatively, and other possibilities of social interlocutions. The artistic orientation towards the social and experimental has flourished cyclically over the last century (this last phase from the 1990s on) throughout a diversity of geographical locations. Among other theorists, philosophers and artists, Claire Bishop in her book Artificial Hells: Participatory Art and the Politics of Spectatorship, offers extensive research and as well as problematizations of what she refers to as the 'social turn' in art, which could also be described as an 'experimental turn' in art. (BISHOP, 2012)

\section{Collective Process for Haptic Thinking and Moving}

Throughout the laboratory-seminar that I facilitated in Madrid, the challenges and intentions were to create a space to navigate playfully and mindfully back and forth between methodological and conceptual inquiries and experimental practices, activating and integrating a transversal thinking that manifests and translates itself in move-

Dasha Lavrennikova, Haptic Thinking and Experience through Collective Artistic Research. 


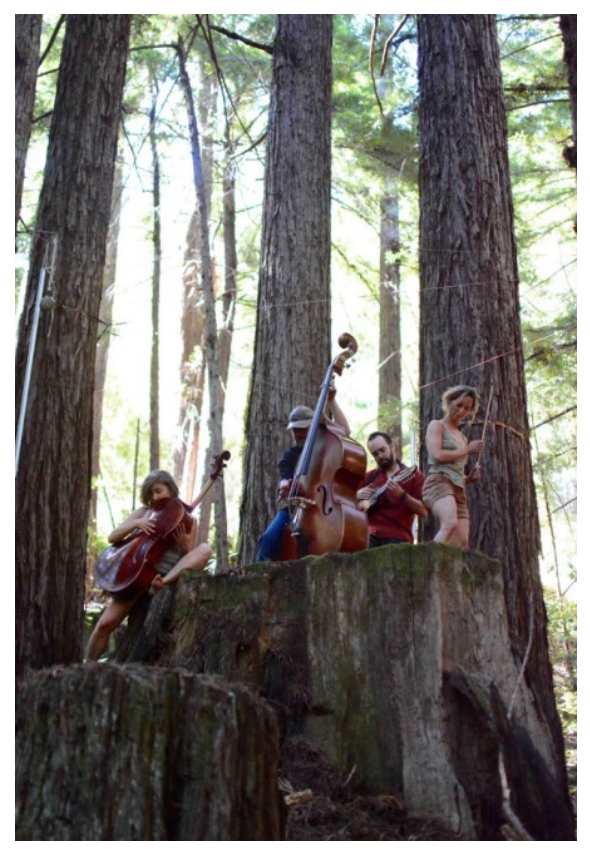

Fig. 3 - Dasha Lavrennikov, Roots Harmonics Performance, Djerassi Resident Artist Program, Anya Yermakova, Dasha Lavrennikov, Sebastian Perez. Santa Cruz, 2018.

(Photo: Dasha Lavrennikov) 
ment, sound, speech, written words, images, actions. Through this arts lab experience we reached a place that was on the borderlines of artistic languages and modalities of thinking: movement images, sound images, visual images, synesthetic images and action images. All these are made up of kinaesthetic images: fluctuating primarily between the visual, auditory and tactile. Although taste and smell are likewise brought in through an expanded sense of both our sensory facilities and our imagination: tasting one's own or someone else movement texture, sensing the entire body's capacity to digest, ingest, taste and devour a space, one's own movement, or the other's presence. Smelling as an extension of breath, inspiration, expiration, smelling another's aura, a color, an object, one's own self in motion.

When we alternate between modalities of thinking and doing, a form of thinking in the act, our attention is a foundational element of the creative process, as it is in our dayto-day life. When we bring an awareness to where our attention is and goes, as well as the possibility of expanding, interrupting, intervening, insisting, redirecting, and deepening our attention, we begin to play, propose and compose collectively with the space and others. Our attention can be focused, multi-tasking, wandering, etc. Each mode of attention generates a different quality of presence, perceptual space and states of mind-body. This can be manifested in written, spoken, drawn, sound, movement or hybrid languages.

When working with improvisational and compositional dynamics in the space, using scores and exercises adapted from dance and theatre, we work with the idea of "composing ourselves to be seen" and experienced by others. This composition of self in and with space-time and other is based on our perception; perception is organization, in motion. This is something we can witness in others and ourselves on an everyday basis. One moves and acts in and with the world based on their perception of that world. With the commitment to embrace, stimulate and celebrate an epistemological diversity, throughout the collaborative artistic and pedagogical practices, requires us to gradually sculpt and tune an environment and thus an experience collectively, that intends to deconstruct or at the least bring into question, a diversity of social, relational, micro-political, spatial- 
temporal conventions manifested in the way we perceive, move through, and understand the world. Shifting away from binary, logo centric, self-centered, universalizing modes of existence is a gradual process that requires thinking, and thus practicing otherwise.

A theme that appears constantly throughout the work I propose in the arts lab (inspired in part by "Asymmetrical Motion" a method developed by Lucas Condro, an Argentian dance maker living in Madrid), is circulating between the whole and its parts, in relation to the body and space in its organic, poetic and relational functions. Likewise, there is a process of circulation between observing, naming and embodying. One concrete working structure and phase of the laboratory explored orienting, disorienting and reintegrating the gaze, the eye, (which allows hybrid experience of observing, embodying, naming), the function of seeing in motion. We worked with the physicality, multi-sensoriality and multiplicity of gaze: as an extension of the spine, as an extremity that reaches in and out of the space, as an affectionate muscle (6 extra ocular muscles), that communicates our internal state of mind-body to the world and internalizes, senses and filters our environment (as an extension of our other senses). According to Yangping Gao: "It is argued that an understanding of eye muscle proprioception is a necessary part of the understanding of the physiology and pathophysiology of eye movement control and that it is also essential to an account of how organisms, including man, build and maintain knowledge of their relationship to the external visual world." Gao evokes Winckelmann's notion of the haptic gaze, a somaesthetic and aesthetic experience, developed in Winckelmann's experience and theory of art. How can our process of seeing the world, as well as art, not be merely through a glance but a different optical mode, what Winckelmann describes as "contemplative gaze" (betrachtung). This distinctive way of looking is activated through a visually haptic engagement, during the aesthetic experience. It affects the way one perceives, is influenced by, and responds to their environment and intrinsically resonates in and forms their creative gestures (movement, sound, speech, writing, tracing, sculpting).

In order to share the open-ended conclusions captured in the collective process of 


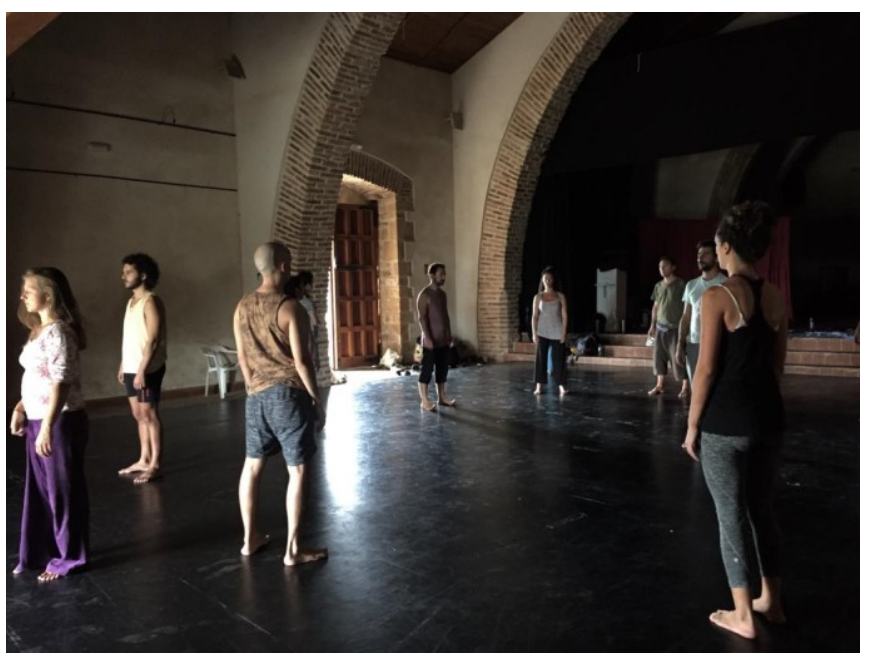

Fig. 4 - Dasha Lavrennikov, Soma Lab 2019, Body, Movement Contact Improvisation Research, Alanis de la Sierra, Spain, October, 2019.

(Photo: Dasha Lavrennikov)

Dasha Lavrennikova, Haptic Thinking and Experience through Collective Artistic Research. 
investigation-creation during the arts lab, below I share the multi-voiced complementary and contrasting discoveries, revelations and questions that came out of the arts lab in Madrid captured on colorful post-its that we then mapped in space.

- Mirar con el cuerpo, tocar con la mirada

- Mirar el mundo con mi mirada nueva tiene que ver con confianza. Despegarse de prejuicios e ideas preconcebidos es también despojarse de miedos y sospechas.

- La práctica del uso del tiempo como un espacio que se abre, es dinámico y flexible, me permite observar en movimiento. Posibilitando tocar la pura acción con menos juicio y libertad. Poder saborear, cambiar saber e sabor.

- Gaze from the outside to the inside as a bridge translating visual inputs into movement patterns (works on subconscious).

- ¿Como se dé la conexión y la desconexión de la mirada? La no intención y la pregunta, solo mirar yo el presente, inocencia, y curiosidad. La creación del misterio, atención, direccion.

- Poner mi dirección de mirada en la mirada de un otro, posibilita una construcción de imaginario en común susceptible de ser transformado.
- ¿Hay libertad en control y descontrol en la mirada? La sensación de perder el control, me dio la sensación de perder intensidad. Pero descubrí que podía dejar el control y perderme en las líneas.

- La mirada como observadora. Mirar la periferia del objeto permite ver el objeto como algo neuvo. Mas despojado de la información o juicio que lleva.

- ¿Cómo agotar todas las posibilidades?

- ¿De qué depende la intensidad de la mirada? Dos factores determinan la intensidad de la mirada: 1. Tono muscular: con el suspiro de alivio puedo modificar mi tono muscular y limpiar exceso de intensidad 2 . Deseo de atraer, de ser preciso en mi observación.

- Ponerles ojos a las cosas las vuelve misteriosas (unas más que otras) y eso me genera una necesidad de mirarlo (porque no lo entiendo del todo, es raro, a veces da risa y a veces mal rollo.

- Existen tensiones que conducen la mirada ajena a nuestra intención.

- La mirada es poderosa. Pueda ser vincular y al mismo tiempo inhibir el vincula. Por ahora no podria decir de que depende.

- La mirada es amplia y generosa, podemos ver más de lo que estamos viendo.

- La mirada como una acción.

- ¿Que se mira cuando se mira? ¿La luz de la vida o la luz de la muerte? 
- In-vol-ver

- ¿Cuál es la relación directa entre la mirada y cómo se organiza el cuerpo? El deseo es el deseo de ver y el deseo de mover para poder ver. Escucha - deseo - no intención.

- Hay experiencias que pos lo efímero y su grado de sensibilidad es difícil conducirlas en un registro que uno mismo y los demás puedan leer en (con) el tiempo.

- La libertad en la mirada: la libertad en la mirada viene con la columna. Mirada sin intención. No poner intención a la mirada requiere que estés en el presente.

- ¿Como activar la mirada práctica para dejarse contagiar? Afirmación: (estilo manifestó) Hay que entender la Mirada como juego, hay que desdramatizar, dejarse estar, dejarse ver.

- ¿Porque elijo lo que elijo?

- Como ejercitar las operaciones espaciotemporal de la mirada? Calidad que cambia cuando el ojo recibe las imágenes y sus tiempos. Diferencia entre buscar y encontrar.

- Considerando el imaginario propio en su diferencia o semejanza con imaginarios generalizados socialmente e culturalmente, en su relación a estructuras de pensamiento condicionados social e históricamente. ¿Podemos ser inherentes a un contexto? ¿Podemos salir? Podemos cons- truir un nuevo cuerpo totalmente y radicalmente distinto?

- How do I manifest myself in relation to the space which is embodied in myself through the gaze...as a constant flow of images? What is to desire? Cosa es el deseo?

- El trabajar en el borde de una paradoja, de un imposible, para encontrar en ese borde, en esa tensión, lo vital, lo inesperado. ¿Como me muevo acompañado, en soledad? ¿Puede la mirada traer todo lo que toco?

- ¿Cómo creamos encuentros accesibles? Dejarse ver, para poder ver.

- ¿Cómo desconectar, visibilizar, e contra cargar el contenido estereotipado o colonizado de una imagen? Detectar estructuras sociales-políticas éticas de una imagen, cambiar el contenido de la imagen.

- Solo puedo partir de mi mirada de todas. Mi Mirada externa como otro cuerpo participando, creando, ¿investigando? Dejar ver mi mirada para descubrir/encontrar lo que estoy deseando. 


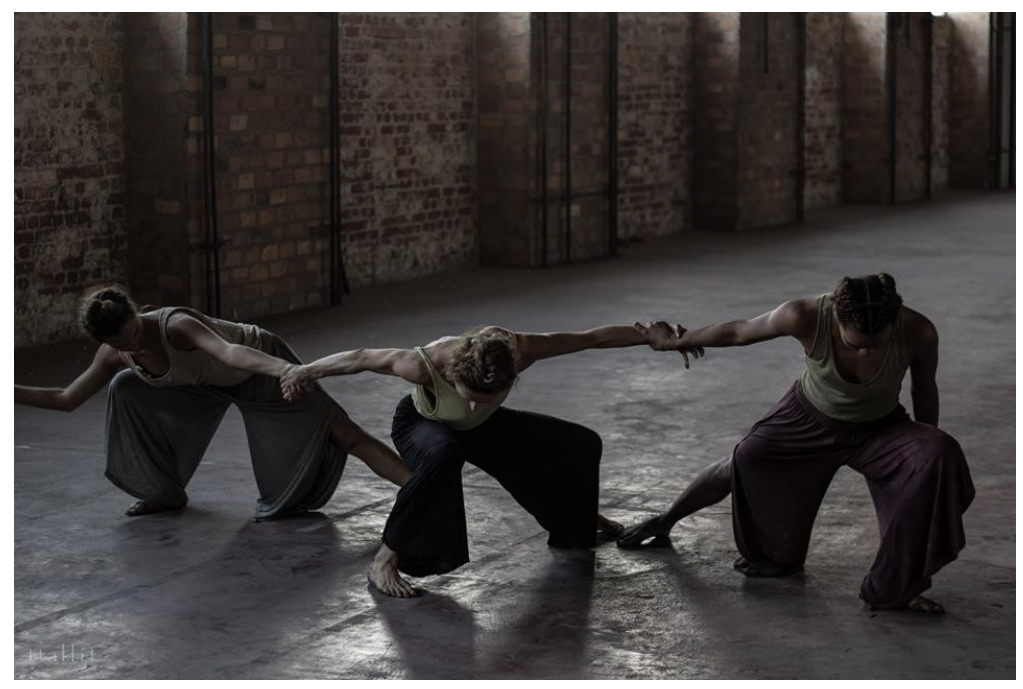

Fig. 5 - Ico Project, Dasha Lavrennikov, Nora Barna, Inae Moreira, Rio de Janeiro, Brazil, 2017.

(Photo: Marcelo Hallit - ICO "Jeito de ser" ou "Ser Estar" em Tupi Guarani) 
In the impossible attempt to conclude and thus continue (re)searching, the artistic laboratory is reconfigured back and forth between experience and reflection, in dialogue with its relevance in today's contemporary world. The arts lab has not yet been fully captured and identified as a formal practice and process, and the term continues to be freely used and interpreted by a diversity of professional artists, amateurs, curators, etc. Like the notion of dance and performance itself it is in constant evolution, involution and reconfiguration. There has been both a process of insisting on establishing criteria and standards for what is an artistic laboratory, encompassing artistic research, while simultaneously there has been a hesitancy in defining and pinning down exactly what it is, as well as what it is not. Throughout my research and practical experience, the following elements persist.

\section{Notas}

${ }^{1}$ Research-creation is an emergent category, a complex intersection of experimental art practice, theoretical concepts and research. In particular, some very important and innovative investigation in the field of research- creation has been developed within the context of the SenseLab founded in Concordia University, directed by Erin Manning and Brian Massumi. This work is discussed in depth by Manning in the text Ten Propositions for Research Creation. Research-creation is in dialogue, yet not interchangeable, with the concepts of artistic- research as well as practice-research, part of a diversity of inter-related terminology and transdisciplinary methodologies that have been developed between and on the thresholds of the arts and academic spaces.

\section{Referências}

ANTOON, van den Braembussche. Thinking Art: An Introduction to Philosophy of Art. Amsterdam: Springer Science + Business Media B.V, 2009.

BISHOP, Claire. Artificial Hells: Participatory Art and the Politics of Spectatorship. London: Verso, 2012.

DE DUVE, Thierry. Sintoma e intuição. (Entrevista). Novos estud. - CEBRAP, São Paulo, n. 79, nov. 2007. Disponível em http://dx.doi.org/10.1590/S010133002007000300011 
DELEUZE, Gilles. On Spinoza. Lectures by Gilles Deleuze, 2007. Disponível em http://deleuzelectures.blogspot.com.br/200 7/02/on-spinoza.html

DEWEY, John. Art as Experience. Translated by Vera Ribeiro. São Paulo: Martins Fontes, 2010.

FEITOSA, Charles. Investigation and Creation: A Dialogue between Vera Mantero and Andre Lepecki. O Percevejo Online, PPGAC/UNRIO, v. 6, n. 1, jan.-jun, 2014. Disponível em_http://www.seer.unirio.br/index.php/opercevejoonline/article/view/5070

GUATTARI, Felix. The Three Ecologies. London: The Athlone Press, 2000.

GUMBRECHT, Hans Ulrich. Production of Presence: What Meaning cannot convey. Rio de Janeiro: Contraponto/Editora PUCRio, 2004.

LEPECKI, André. Performance and Corporeality. Points of Convergence. Lecture by André Lepecki. Jan. 22, 2014. Artmuseum. Disponível em_https://artmuseum.pl/ en/doc/video-performans-i-cielesnosc

LEVI-STRAUSS, Claude. The Savage Mind. London: George Weidenfeld and Nicolson Ltd, 1966.

LITTLE, Nina; NELSON, Lisa. Lisa Nelson in Conversation with Nita Little. Movement Research, 2006. Disponível em https:// movementresearch.org/publications/criticalcorrespondence/lisa-nelson-inconversation-with-nita-little.
MANNING, Erin; MASSUMI, Brian. Thought in the Act: Passages in the Ecology of Experience. Minneapolis: Minnesota Press, 2014.

OITICICA, Hélio. The Museum is the World. Org. Cesar Oiticica, Rio de Janeiro: Beco do Azougue, 2011.

OITICICA, Hélio. The Senses Pointing Towards a New Transformation. Written for Touch Art Symposium, California State College, 1969.

PARRA, Natalia Jarra. El Arte Como Ejercicio Experimental de la Libertad. Museo de la Solidaridad Salvador Allende: Coloquio Educar para transformar. Disponível em http://www.autoresdeluruguay.uy/bibliotec a/danilo_trelles/lib/exe/fetch.php?media=sf el_arte_como_ejercicio_experimental_de_I a_libertad._natalia_jara_parra.pdf

PEETERS Jeroen. Bodies as Filters: On Resistence and Sensoriness in the work of Boris Charmatz, Benoit Lachambre and Meg Stuart. Verwantschappen \#2 project at Maasmechelen Cultural Centre, 2004.

PELBART, Peter Pál. The Thought of the Outside, the Outside of Thought. Angelaki Journal of the Theoretical Humanities, v. 5, n. 2, Aug. 2010.

ROLNIK, Suely. Esferas da Insureição. São Paulo: N-1 edições, 2018.

SPANBERG, Marten. The Doing of Research. http://martenspangberg.se/sites/martenspa ngberg.org/files/research_06.pdf 
STAMER, Peter. What is an Artistic Laboratory. Knowledge in Motion: perspectives of artistic and scientific research in dance.

Critical Dance Studies. Bielefeld: Transcript, 2007.

TAYLOR, Diane. The Archive and the Repertoire: Performing Cultural Memory in the Americas. Durham: Duke University Press, 2003. 